\title{
中学校の体育授業における学習者の学習観 および学習方略の関連に関する研究
}

\author{
小野 雄大 ${ }^{1)}$ 友添 秀則 ${ }^{1)}$ 高橋 修—2 \\ 深見 英一郎 ${ }^{1)}$ 吉永 武史 ${ }^{1)}$ 根本 想 ${ }^{3)}$
}

Yuta Ono ${ }^{1}$, Hidenori Tomozoe ${ }^{1}$, Shuichi Takahashi ${ }^{2}$, Eiichiro Fukami ${ }^{1}$, Takeshi Yoshinaga ${ }^{1}$ and So Nemoto ${ }^{3}$ : Conceptions of learning and learning strategies of students in junior high school physical education. Japan J. Phys. Educ. Hlth. Sport Sci.

\begin{abstract}
The importance of students' conceptions of learning has been highlighted as a way of thinking that affects learning behavior. Because physical education is motor learning, it is assumed that learners construct learning concepts that are unique to physical education. However, no study has yet investigated the essence of such learning concepts and the relationship between learning concepts and strategies. To elucidate the relationship between learning concepts and strategies in physical education, this study focused on junior high school students and developed a scale to evaluate learning concepts and learning strategies in junior high school physical education. After a preliminary survey, a major questionnaire survey targeting 2,498 students in public and private junior high schools nationwide revealed the following:
\end{abstract}

1) 5 factors were extracted as learning concepts: "learning motor skills", "cultivating communication skills", "acquiring knowledge on body and movement", "feeling the attraction of physical activities", and "improving physical capacity". Students' learning concepts showed a tendency similar to the domain of the physical education subject.

2) 7 factors were extracted as learning strategies: "emphasis on learning discipline", "cooperative effort with peers", "creation of fun", "challenging work", "fair work", "engagement with teachers", and "thinking and judgement". These learning strategies indicate factors that are unique to motor learning.

3) A review of the differences in grades and gender confirmed that all factors in the 2 scales were more significant for students in their second or third year of junior high school compared to those in their first year. Additionally, boys emphasized cooperative effort, whereas girls emphasized the relationship with teachers.

4) A relationship between learning concepts and strategies was revealed, indicating that learners tackle learning tasks while utilizing their acquired knowledge and skills.

Key words : metacognitive, course of study, active learning, scale development キーワード : メタ認知, 学習指導要領, アクティブ・ラーニング, 尺度開発

1) 早稲田大学スポーツ科学学術院

干 359-1192 埼玉県所沢市三ヶ島 2-579-15

2）国立教育政策研究所

干 100-8959 東京都千代田区霞が関 3-2-2

3）育英短期大学

干 370-0011 群馬県高崎市京目町 1656-1

連絡先 小野雄大
1. Faculty of Sport Sciences, Waseda University 2-579-15 Mikajima, Tokorozawa, Saitama 359-1192

2. National Institute for Educational Policy Research 3-2-2 Kasumigaseki, Chiyoda-ku, Tokyo100-8959

3. Ikuei Junior College 1656-1 Kyomemachi, Takasaki, Gunma370-0011

Corresponding author y-ono.sps@aoni.waseda.jp 


\section{I 問題と目的}

\section{1. 体育授業における「学習観」と「学習方略」 の重要性}

2014 （平成 26）年に中央教育審議会から出さ れた諮問「初等中等教育における教育課程の基準 等の在り方について」を契機に, 今後の教育実践 の柱として「アクティブ・ラーニング」の重要性 が叫ばれるようになった.「アクティブ・ラーニ ング」とは,「課題の発見と解決に向けて主体的・ 協働的に学ぶ学習」（中央教育審議会, 2014）と され，アクティブ・ラーニングの充実によって, 学習者の知識・技能の定着を促し, さらには学習 意欲の向上などにつながることが期待されている （中央教育審議会，2014）.

そして，2017（平成 29）年 3 月に告示された 新学習指導要領（以下「新指導要領」と略す）で は,アクティブ・ラーニングをもとにした「主体的・ 対話的で深い学び」（文部科学省, 2017a, p.3) の実現が打ち出され，学習内容に関する言及に留 まらず，新たに学習方法の充実についても求めら れた。こうした新指導要領の方向性は，体育科・ 保健体育科（以下「体育」と略す）の教科目標に も強く反映されている.

新指導要領では, 各教科の教科目標に, 教科の 特質に応じて物事を捉えるための「見方・考え 方」が記載されている．中学校体育分野の「見方・ 考え方」については，「運動やスポーツを，その 価值や特性に着目して, 楽しさや喜びとともに体 力の向上に果たす役割の視点から捉え，自己の適 性等に応じた『する・みる・支える・知る』の多 様な関わり方と関連付けること」（文部科学省, 2017b，p.25）と整理されている。 すなわち，今 後の体育では，上記のような体育の見方・考え方 を核としつつ，学習者自身による「主体的・対話 的で深い学び」という学びの過程を辿ることが目 指される。したがって, 新指導要領では, 学習者 自身が「どのように学ぶのか」という「学習方法 のあり方」が, より重要な検討課題として位置づ けられた（友添，2017）。
そこで本研究では，体育授業における学習者の 学習方法のあり方を考えるために，学習者自身が 有する「学習観」と「学習方略」の関連に注目し たい，学習観は，知識の獲得や利用を方向づける メタ認知の重要な一側面であり（藤村，2008）, 学習方略に影響を与える重要な思考様式とされて いる（篠ヶ谷，2008；鈴木，2013；植木，2002； 植阪，2010)。このことからも，学習者の学習方 法のあり方を模索していくためには，単に学習方 略のみを取り上げるのではなく, 学習観と学習方 略の関連にも着目して検討を進める必要がある。

\section{2. 本研究における「学習観」の捉え方}

そこで, まず，学習観を扱ったこれまでの研究 を概観すると，大別して 2 つの捉え方が提案され ている.

1つ目は，「学習とはどのようなものか」とい う問いを軸として学習観を扱った研究である（北 村ほか, 2003 ; Marton et al., 1993 ; Purdie et al., 1996; 鈴木，2013）。例えば, 鈴木（2013）は，「学 習という言葉から連想される言葉や場面とは何 か」などの問いから,「意味理解志向学習観」,「暗 記再生志向学習観」,「学校依存的学習観」,「義務 的学習観」の 4 因子からなる「学習観尺度」を開 発した。これらの研究で用いられた学習観は, 広 く学習一般に対する考え方を示している.

2つ目は，「成績を上げるためにどのような方 法が良いか」というように，「効果的な学習方法 に関する信念」として学習観を报った研究であ る（堀野ほか, 1990 ; 市川ほか, 1998 ; 植木, 2002）。堀野ほか（1990）は，「失敗に対する柔軟 性志向」と「思考過程の重視」という2 因子から なる学習観の側面を明らかにし,市川ほか（1998） は, その 2 因子に「方略志向」と「意味理解志向」 を加えた 4 因子の「学習観尺度」を開発している. その後, この「学習観尺度」はいくつかの改変を 経て,「認知主義的学習観」,「非認知主義的学習観」 の 2 つの上位尺度の存在を見出している（市川ほ か, 2009).

以上を踏まえた上で，本研究では，1 目に挙 げた「学習に対する考え方」を本研究で扱う学習 
観として位置づけて検討を進める。なぜなら,「効 果的な学習方法に関する信念」としての学習観は, あくまでも「効果的な学習方法」に焦点化されて いるため，学習そのものに対する考えを捉えてい くには適さないからである. したがって, 本研究 では,「体育では何を学習するのか」という問い を軸として検討を進めることで，学習者が有する 体育の学習観を明らかにしていく．これにより, 学習者の体育学習そのものに対する考えを直接的 に捉えることが可能になると考えられる.

\section{3.「学習方略」に関する先行研究}

一方で,「学習方略」とは, 「学習の効果を高め ることを目指して意図的に行う心的操作あるいは 活動」（辰野，1997，p.11）とされている. 学習 方略の分類や研究結果は多岐にわたるが，大きく 「認知的方略」,「メ久認知的方略」,「外的リソース」 の3つに分けることができる（植阪，2010）.

1 つ目の「認知的方略」は, 学習内容の修得に 向けて工夫を施す学習方略である. 具体的には, 学習内容を覚えるために反復して暗唱したり書い たりする「リハーサル方略」, イメージ化したり， すでに修得している知識をつけ加えることによっ て学習内容を覚えやすい形に変換する「精緻化方 略」，学習内容が相互に関連を持つようにまとめ る「体制化方略」が挙げられる.

2つ目の「メ夕認知的方略」は, 自身の知的な 状態に注意を向ける学習方略である. 具体的には, 学習者自身で学習目標を確立し, その達成度を評 価することで, 自身の理解度を確認する「理解モ ニタリング方略」や, 自身の学習状況や学習の質 を評価する「自己評価方略」などが挙げられる.

3つ目の「外的リソース」は, 道具や他者とい つた外的リソースを活かす学習方略である.特に, 教師や仲間から援助を受けるといった「援助要請 方略」は，単にわからないことを教えてもらうと いうメリットを越えて, 他者との相互作用を通し て問題解決のスキルを学ぶ重要な機会として捉え られている（Nelson et al., 1983）.

以上は，一般的な学習場面を想定した学習方 略の分類であるが, 他方では, 教科に特化した
学習方略の研究も多く行われている. 実際に, 算数・数学科（廣瀬ほか, 2013 ; 市原・新井, 2005, 2006; 北村ほか, 2003 ; 押尾, 2017 ; 寺 西, 2008）や英語科（赤松・藤岡, 2015 ; 篠ヶ 谷, 2014), 国語科 (市原・新井, 2005 ; 押尾, 2017），地理歴史科の歴史（村山，2003）におけ る学習方略の研究を確認することができる. 中学 生・高校生の「歴史学習方略」の構造を明らかに した村山（2003）は，学習方略の使用を促進する 教育介入プログラムの作成を提言するなど, 教育 実践との関係から, 各教科に特化した学習方略研 究のさらなる蓄積の必要性を指摘している. 以上 を体育に転じて考えてみると, 特に体育は運動学 習を主とする学習方法が教科の独自性の 1 つであ ることから（友添，2010）, 学習者の中に体育特 有の学習方略, さらには体育特有の学習観が構成 されていることが推察される.

\section{4. 体育を対象とした「学習観」と「学習方略」 に関する先行研究}

そこで，体育を対象にした先行研究を概観する と, まず, 体育授業における学習者の学習観に着 目した研究はほとんど行われていない.より厳 密にいえば，「体育授業における学習観」という トピック自体は，例えば近年の「構成主義的学習 観」や「行動主義的学習観」に代表されるように 議論の対象となっているものの（例えば, 成家, 2012 ; 鈴木, 2014), その際に, 「学習者自身の学 習観」を構成する要素や, その個人差を規定する 次元の内実については射程外にあると言わざるを 得ない.

一方で, 体育授業における学習者の学習方略に 関する研究については, 伊藤 (2001）の研究が挙 げられる。伊藤（2001）は, 学習動機と学習方略 の関連を明らかにする中で, 体育授業における 学習方略を測定する尺度注 ${ }^{1)}$ を開発した。これは, 速水（1993）が開発した学習方略尺度の中から, 体育の学習場面に関連が深いと考えられる 15 項 目を選び，項目の表現に修正を施した上で， 3 因 子(「一般学習方略」,「めあて方略」, 「努力調整 方略」）を抽出した尺度である。しかしながら, 
速水（1993）が見出した尺度項目は，一般的な学 習場面を想定したものである，そのため，伊藤 （2001）が用いた尺度開発方法では，体育特有の 潜在因子・項目がこぼれ落ちている可能性が考え られる．また，極端に信頼性の低い因子が含まれ るなど，尺度全体を通して，項目内容や項目数の 再検討が必要である。したがって，尺度開発方法 から見直した, 新たな体育学習方略尺度の開発が 望まれる.

こうした中，鐘ヶ江ほか（1985a，1985b）や高 橋（1989）が，「学習者からみた体育の授業構造」 を明らかにした研究は，本研究に対して重要な 示唆を与えてくれる。まず, 鐘ヶ江ほか（1985a, 1985b）は, 中学生の体育授業の態度構造として, 「成果」,「楽しさ」,「仲間」,「先生」の 4 因子を 見出した. さらに，高橋（1989）は，この研究結 果やシーデントップ（1981）の体育目標構造を踏 まえ, 体育の教科内容として「情意」,「運動技能」, 「社会的行動」,「認識」の 4 領域を見出した. そ の後,こうした研究の知見を踏まえて, 具体的な 体育授業評価尺度として,「形成的授業評価法」(長 谷川ほか, 1995 ; 高橋ほか, 1994）や「診断的・ 総括的授業評価法」（高田ほか，2000）が開発さ れている。これら一連の研究は，授業評価方法の 確立に重点を置いており，体育授業における学習 観や学習方略の実態に焦点を当てて検討したわけ ではないが，学習者の視点から体育授業を検討し ていくことの重要性を実証的に示している.

\section{5. 本研究の目的}

以上からもわかるように，学習観および学習 方略は, 学習者の自ら学ぶ力を育成していく上 で, 重要な要素として位置づけられる（瀬尾ほか, 2008 ; 植阪，2010)。このことからも，体育授業 における学習者の学習観および学習方略に関わる 諸種の実態を実証的に明らかにすることは，体育 の教育実践の質の向上を図っていく上でも大きな 意義があると考える.

そのために, 各学校段階を対象に検討を進める 必要があるが, 本研究では, まずは中学生を対象 として, 以下の 4 点について明らかにする.
1つ目に,「中学生用体育学習観尺度」を開発し, 中学生が体育においてどのような学習観を有して いるのかを明らかにする。2つ目に，「中学生用 体育学習方略尺度」を開発し，中学生が体育にお いてどのような学習方略を用いているのかを明ら かにする. 3つ目に，学習観と学習方略それぞれ の学年差・性差を明らかにする４つ目に，両尺 度を用いて, 中学生の体育授業における学習観と 学習方略の関連を明らかにする。

なお，本研究で開発する 2 つの尺度は，将来的 に体育授業への適用を目指す。しかしながら，教 育実践への適用を前提として尺度開発を行う場 合，授業場面での使い易さへの考慮から，尺度項 目数を減らすなどの工夫が求められる．換言すれ ば，こうした措置は，本来抽出されるべき尺度項 目を見落としてしまう可能性を孕む．そのため， 本研究では，まずは教育実践への適用を考慮せず に尺度開発を行い，尺度の簡易化については今後 の課題としたい.

\section{II 予備調查}

\section{1. 目的}

予備調査の目的は,「中学生の体育授業におけ る学習観」および「中学生の体育授業における学 習方略」に関する記述を収集・精選することであ る.

尺度開発の方法には，一部の測定対象者に対し て自由記述による調査や面接を行って項目の素材 を得る方法，あるいは関連のある構成概念につい て既存の尺度の項目を参考にする方法など様々あ るが（南風原，2009），本研究では，自由記述方 式の予備調査および面接調査を通して，記述を収 集・精選する．これにより，体育特有の尺度項目 の収集に努める.

\section{2. 方法}

\section{1. 調査時期・対象者および手続き}

\section{1）質問紙調査（自由記述）}

調査は, 2016（平成 28）年 9 月に, 東京都の3 校の公立中学校において実施した。内訳は，中学 
校 1 年生から 3 年生の計 281 名（男子 141 名, 女 子 140 名）であった. 調査の手続きは, 調査対象 者の在籍する学級単位で授業時間を用いて集団で 実施された。 なお, 全ての学級が, 男女別習で授 業を行っていた。

\section{2) 面接調查}

自由記述の調査対象であった 3 校のうち, 学校 長の承諾を得ることのできた 2 校を対象にして, さらに詳しく項目を収集するために面接調査を実 施した. 上記の 2 校からそれぞれ 18 名の計 36 名 (各校 1 学年 6 名 $\times 3$ 学年)を抽出し, 集団面接(各 回 3 名ずつ, 計 12 回）を実施した. 面接調査の 発話データは, 面接対象者に了承を得た上で IC レコーダーに録音し，文字化したものをデータと して用いた。

\section{2. 倫理的配慮}

質問紙調査は無記名式で行い, 調査対象者の回 答の右名性が確保されることを質問紙に明記し た. 調査に対する同意については, 質問への回答 は自由意志であること, 答えられない項目や, 答 えたくない項目は無理に答えなくてよいことを質 問紙に明記することによって得られたものと判断 された。 また，面接調査においては，このことを 口頭で伝えた.これらの方法は全ての学年におい て共通であった。

\section{3. 調査内容}

1)「中学生の体育授業における学習観」について まず，「あなたは，体育の授業ではどのような ことを学ぶと思うか」という質問文を教示し, 自 由記述によって回答を求めた. 自由記述の後に実 施した面接調査においても, 同様の質問を行い, 回答を求めた.

\section{2）「中学生の体育授業における学習方略」につい て}

「あなたは，体育の授業にどのように取り組ん でいるか」という質問文を教示し, 自由記述によ って回答を求めた. 面接調査においても, 同様の 質問を行い, 回答を求めた。

\section{3. 結果}

自由記述と面接調査の回答について，まず質問 に関連のない回答を除外し，その後に記述を文節 単位で抽出したところ,「中学生の体育授業にお ける学習観」に関する記述について 911 個,「中 学生の体育授業における学習方略」に関する記述 について 489 個を収集した。

次に, これらの記述について, 本研究者と体育 科教育学を専門とする大学院生 3 名の評定者が内 容の類似性に基づいて分類し，全員が合意するま で議論を重ねた結果,「中学生の体育授業におけ る学習観」の構成概念として,「運動技術の習得」, 「コミュニケーション能力の涵養」,「運動の魅力 の感受」,「身体についての理解」,「運動について の知識」「身体能力の向上」という 6 つが見出さ れた. また,「中学生の体育授業における学習方略」 の構成概念として,「仲間との協力的な取り組み」, 「学習規律の重視」,「楽しさの創出」,「挑戦的な 取り組み」,「思考・判断」,「教師への関わり」,「公 正な取り組み」の7つが見出された. 尺度項目の 作成は，ここで見出された各概念に分類された記 述内容をもとに行った. その際, 内容が類似する 記述は集約するなど, 記述の明確化を図った。こ のような過程を経て作成された項目は, 8 名の中 学校の現職教員に協力を得て, 本研究者と共に検 討し, 解りやすい表現となるように修正した.

次に, 内容的妥当性の検証を行った. 内容的妥 当性の検証の手続きについては, 体育科教育学を 専門とする大学院生 8 名に対して, 学習観に関す る 33 項目, 学習方略に関する 40 項目を一覧にし て提示し, 中学生の体育授業における学習観に関 する各項目を上記の 6 つ, 体育授業における学習 方略に関する各項目を上記の 7 つ構成概念に分 類してもらい, その一致率によって判定するもの とした。その際，一致率が $60 \%$ 未満の項目を削 除することとした。

検証の結果, 最終的に中学生の体育授業におけ る学習観を測定する項目として 29 項目, 中学生 の体育授業における学習方略を測定する項目とし て 36 項目が選定された. 中学生にも理解が容易 になるよう, 中学校の現職教員により, 項目表現 
の修正を実施した。

\section{III 本調查}

\section{1. 目的}

本調査では, まず, 予備調査で選定された項目 をもとに,「中学生の体育授業における学習観」 および「中学生の体育授業における学習方略」を 測定する尺度を開発し，尺度の因子構造を明らか にする．次に，学年や性別の違いによる体育授業 における学習観および学習方略の特徴について明 らかにする. 最後に, 体育授業における学習観と 学習方略の関連について明らかにする.

\section{2. 方法}

\section{1. 調査時期・対象者および手続き}

調査は, 2016（平成 28）年 11 月から 2017 （平 成 29）年 1 月に, 青森県, 茨城県, 東京都, 埼玉県, 大阪府, 福岡県の公立および私立学校計 13 校の 中学生 (全学年) を対象として実施した. 内訳は, 1 年生が 782 名（男子 384 名, 女子 398 名), 2 年 生が 896 名（男子 421 名，女子 475 名), 3 年生 が 820 名（男子 402 名，女子 418 名）の計 2,498 名（男子 1,207名，女子 1,291 名）であった。 そ のうち,記入漏れや記入ミスのあったものを除き, 有効回答者 2,438 名 (男子 1,170 名, 女子 1,268 名) を分析の対象とした。調査の手続きは，調査対象 者が在籍する学級単位で，授業時間を用いて集団 で実施された。なお，全ての学級が，男女別習で 授業を行っていた。

また，全調査対象者のうち，3 校計 702 名（男 子 325 名, 女子 377 名）の対象者には, 再検査法 による信頼性の検討を行うため, 約 3 週間の間隔 を空けて 2 回目の調査を実施した.

統計処理には, SPSS（Version24.0）を使用した.

\section{2. 倫理的配慮}

予備調査と同様に，調査に対する同意について は，質問への回答は自由意志であること，答えら れない項目や，答えたくない項目は無理に答えな くてよいことを質問紙に明記することによって,
得られたものと判断された。これらの方法は全て の学年において共通であった。

また, 再検査法による信頼性の検討を行うため, 先述した 3 校計 702 名の調査対象者には記名を求 めた．記名を求めるにあたり，記名は個人を特定 するためではなく 1 回目と 2 回目の回答を照合す ることが目的であることや，記名を拒否すること ができること，学級担任などが回答を見ることは なく成績評価にも一切影響することがないことを 明記した。ささらに，データ入力後は直ちにシュレ ッダーによって調查用紙が破棄されることも明記 し，口頭でも伝えた。

\section{3. 調查内容}

1) フェイスシート

学年・性別に加えて,「体育授業が好きか嫌い か」,さらには「これまで, 『体育の授業で学ぶ内 容』や『体育の授業に対する自分の取り組みかた』 について考えたことがあるか」という質問への回 答を求めた。

なお，本研究では上記の回答のうち，「体育授 業の好き・嫌い」に対する回答を尺度の妥当性検 証に用いることとした。なぜなら，先行研究で は，他教科（数学・国語など）を対象にした研究 ではあるものの，その教科が好きであるほど，学 習者の学習方略の使用も多彩になることが明らか にされているからである（押尾，2017）。さらに は，体育授業を対象にした研究においては，体育 授業が嫌いな学習者は，体育授業に対して消極的 あるいは回避的態度が多くなること（佐々木・須 甲，2016）また，体育授業を好意的に受け止め， 学習動機が高い学習者ほじ, 多彩に学習方略を 使用していることが明らかにされている（伊藤, 2001).

こうした一連の研究の知見に鑑みれば，体育授 業の好き嫌いによって, 体育授業の学習観と学習 方略使用にも差異が生じている可能性が考えられ る.したがって，ここでの妥当性検証の仮説とし ては，体育授業が好きな学習者ほど，体育授業に おける学習観および学習方略を測定する項目の得 点も高くなり，それに対して，体育授業が嫌いな 
学習者ほど得点が低くなることが予測される.

2）中学生の体育授業における学習観を測定する 項目

予備調査によって選定された 29 項目について, 学習者の考え方にどの程度あてはまるかを,「よ くあてはまる (4 点)」,「あてはまる (3 点)」, 「少 しあてはまる（2 点)」,「全然あてはまらない（1 点)」の 4 件法で回答を求めた.

3）中学生の体育授業における学習方略を測定す る項目

予備調査によって選定された 36 項目について, 学習者の行動にどの程度あてはまるかを,「よく あてはまる (4 点)」,「あてはまる (3 点)」,「少
しあてはまる（2 点)」,「全然あてはまらない（1 点)」の 4 件法で回答を求めた.

\section{3. 結果}

\section{1.「中学生の体育授業における学習観」を測定す る尺度の探索的因子分析}

まず, 中学生の体育授業における学習観を測定 する 29 項目について, 項目分析を行った. 項目 の偏りを検討するため, 平均值が 1.5 以下または 3.5 以上の項目, また, 標準偏差の極端に小さい 項目，頻度の正規分布において特定の度数に 70 \%が集約する項目を検討した結果, 3 項目を削除 した.さらに, 各項目間の相関係数を算出したと

表 1 中学生用体育学習観尺度の因子分析結果（Promax 回転）と因子間相関

\begin{tabular}{|c|c|c|c|c|c|c|c|c|}
\hline 項目 & $M$ & $S D$ & & I & II & III & IV & $\mathrm{V}$ \\
\hline \multicolumn{9}{|l|}{ I 運動技術の習得 $(\alpha=.82)$} \\
\hline 体育の授業では、運動やスポーツの戦術を身につける & 2.97 & .90 & & .77 & .04 & -.02 & -.07 & .05 \\
\hline 体育の授業では、体の上手な動かしかたを身につける & 3.03 & .80 & & .73 & .12 & -.10 & .05 & .05 \\
\hline 体育の授業では、うまく運動するためのコツを身につける & 2.99 & .83 & & .65 & .16 & .02 & .05 & .10 \\
\hline 体育の授業では、色々な用具を使った運動のしかたを身につける & 3.02 & .84 & & .65 & .13 & .05 & .03 & -.03 \\
\hline 体育の授業では、色々な種類の運動のしかたを身につける & 3.17 & .84 & & .61 & -.04 & .01 & .05 & .12 \\
\hline \multicolumn{9}{|l|}{ II コミュニケーション能力の涵養 $(\alpha=.77)$} \\
\hline 体育の授業では、他者を理解することの大切さを学ぶ & 2.75 & .90 & & -.02 & .84 & -.05 & .04 & .04 \\
\hline 体育の授業では、他者と協力することの大切さを学ぶ & 3.11 & .88 & & -.05 & .70 & .08 & .00 & -.07 \\
\hline 体育の授業では、他者から教わるときの態度を学ぶ & 2.85 & .89 & & .20 & .49 & .07 & .12 & -.09 \\
\hline 体育の授業では、他者との心の距離の取りかたを学ぶ & 2.53 & .90 & & .05 & .42 & .03 & .11 & .06 \\
\hline 体育の授業では、他者へのアドバイスのしかたを学ぶ & 2.63 & .89 & & .22 & .41 & .03 & -.10 & -.10 \\
\hline \multicolumn{9}{|l|}{ III 身体と運動に関する知識の修得 $(\alpha=.76)$} \\
\hline 体育の授業では、運動やスポーツのマナーについて学ぶ & 3.21 & .83 & & -.17 & .32 & .83 & -.05 & -.03 \\
\hline 体育の授業では、運動やスポーツの成り立ちについて学ぶ & 2.73 & .88 & & .18 & -.04 & .67 & .33 & .01 \\
\hline 体育の授業では、運動やスポーツが心身に与える影響・効果について学ぶ & 2.92 & .85 & & -.04 & .02 & .67 & .14 & -.05 \\
\hline 体育の授業では、運動やスポーツの意義について学ぶ & 2.92 & .86 & & .25 & -.16 & .51 & -.12 & .14 \\
\hline 体育の授業では、運動やスポーツのルールについて学ぶ & 3.35 & .79 & & -.14 & -.01 & .43 & .02 & -.07 \\
\hline \multicolumn{9}{|l|}{ IV 運動の魅力の感受 $(\alpha=.71)$} \\
\hline 体育の授業では、運動することの喜びを味わう & 3.03 & .95 & & .18 & .01 & -.09 & .76 & .01 \\
\hline 体育の授業では、勝敗を競う楽しさを味わう & 3.05 & .94 & & .18 & -.09 & .16 & .70 & .14 \\
\hline 体育の授業では、運動することの楽しさを味わう & 3.21 & .90 & & -.08 & .02 & .27 & .43 & .06 \\
\hline \multicolumn{9}{|l|}{$\mathrm{V}$ 身体能力の向上 $(\alpha=.74)$} \\
\hline 体育の授業では、持久力を養う & 3.10 & .86 & & .02 & .02 & .02 & .03 & .76 \\
\hline 体育の授業では、筋力を養う & 3.10 & .85 & & -.03 & -.08 & .03 & .02 & .70 \\
\hline 体育の授業では、体の柔軟性（やわらかさ）を養う & 2.70 & .88 & & -.17 & .02 & .08 & .07 & .62 \\
\hline \multirow[t]{6}{*}{ 体育の授業では、瞬発力を養う } & 2.91 & .88 & & -.02 & .10 & .03 & -.03 & .52 \\
\hline & & & I & - & .58 & .17 & .16 & .26 \\
\hline & & & II & & - & .01 & .22 & .41 \\
\hline & & & III & & & - & .38 & .23 \\
\hline & & & IV & & & & - & .18 \\
\hline & & & $\mathrm{V}$ & & & & & - \\
\hline
\end{tabular}


ころ，.70を超えるような高い值はみられなかっ た.

次に, 残った 26 項目について, 探索的因子分 析(最尤法, Promax 回転)を行った. 因子負荷量が, .40 以下の項目および 2 項目間にわたって .40 以 上の因子負荷量を示した 4 項目を削除した. 残さ れた 22 項目について再度, 探索的因子分析（最 尤法, Promax 回転）を行い, その結果 5 因子が 抽出された（表 1).

続いて, 項目の特徵から，抽出された 5 因子に ついて命名を行った．第 1 因子は，「体育の授業 では, 運動やスポーツの戦術を身につける」や「体 育の授業では，体の上手な動かしかたを身につけ る」などの項目を含んでおり，運動技術の習得に 関わる項目が示されていることから，「運動技術 の習得」と命名した．第 2 因子は，「体育の授業 では, 他者を理解することの大切さを学ぶ」や「体 育の授業では，他者と協力することの大切さを学 ぶ」などの項目を含み, 他者とのコミュニケーシ ヨン能力の涵養に関わる項目が示されていること から，「コミュニケーション能力の涵養」と命名 した．第 3 因子は,「体育の授業では, 運動やス ポーツのマナーについて学ぶ」や「体育の授業で は，運動やスポーツの成り立ちについて学ぶ」な どの項目を含み，身体・運動の知識の修得に関わ る項目が示されていることから，「身体と運動に 関する知識の修得」と命名した。第 4 因子は,「体 育の授業では，運動することの喜びを味わう」や 「体育の授業では，勝敗を競う楽しさを味わう」 などの項目を含み, 運動の魅力の感受に関わる項 目が示されていることから，「運動の魅力の感受」 と命名した．そして，第 5 因子は，「体育の授業 では，持久力を養う」や「体育の授業では，筋力 を養う」などの項目を含み，身体能力の向上に関 わる項目が示されていることから，「身体能力の 向上」と命名した.

続いて，尺度の内的一貫性を検討するため，上 記の 5 因子について, 信頼性係数として Cronbach の $\alpha$ 係数を算出した. その結果，第 1 因子 は $\alpha=.82$, 第 2 因子は $\alpha=.77$, 第 3 因子は $\alpha=$ .76 , 第 4 因子は $\alpha=.71$, 第 5 因子は $\alpha=.74$ であ
つた。いずれの因子も，.70 以上の $\alpha$ 係数が算出 されており，一定程度の内的一貫性があることが 確認された。

なお，本研究では，開発した尺度を「中学生用 体育学習観尺度 (以下「体育学習観尺度」と略す)」 と命名した.

\section{2.「中学生の体育授業における学習方略」を測定 する尺度の探索的因子分析}

中学生の体育授業における学習方略を測定する 36 項目について, 項目分析を行った. 項目の偏 りを検討するため, 平均值が 1.5 以下または 3.5 以上の項目，また，標準偏差の極端に小さい項目， 頻度の正規分布において特定の度数に $70 \%$ が集 約する項目を検討した結果，2 項目を削除した。 さらに，各項目間の相関係数を算出したところ, .70 を超えるような高い值はみられなかった。

次に，残った 34 項目について，探索的因子分 析(最尤法, Promax 回転)を行った. 因子負荷量が, .40 以下の項目および 2 項目間にわたって .40 以 上の因子負荷量を示した 4 項目を削除した．残さ れた 30 項目について再度，探索的因子分析（最 尤法，Promax 回転）を行い，その結果 7 因子が 抽出された（表 2)。

続いて, 項目の特徵から, 抽出された 7 因子 について命名を行った，第 1 因子は，「体育の 授業では，メリハリをつけて素早く行動をす る」や「体育の授業では，準備・片付けをしっ かりと行う」などの項目を含んでおり，円滑か つ効果的な学習を遂行するための学習規律に関 わる項目が示されていることから，「学習規律の 重視」と命名した．第 2 因子は，「体育の授業で は，仲間にアドバイスをする」や「体育の授業で は, 責任をもって自分に与えられた役割を果たす。 などの項目を含み，仲間と協力しながら学習を進 める項目が示されていることから，「仲間との協 力的な取り組み」と命名した．第 3 因子は，「体 育の授業では，何事に対してもつまらないと思わ ないようにする」や「体育の授業では，興味や関 心がないことに対しても，楽しく取り組むための 工夫をする」などの項目を含み，自ら進んで楽し 
表 2 中学生用体育学習方略尺度の因子分析結果 (Promax 回転) と因子間相関

\begin{tabular}{|c|c|c|c|c|c|c|c|c|c|}
\hline 項目 & $M$ & $S D$ & $\mathrm{I}$ & II & III & IV & $\mathrm{V}$ & $\mathrm{VI}$ & VII \\
\hline \multicolumn{10}{|l|}{ I＼cjkstart学習規律の重視 $(\alpha=.82)$} \\
\hline 体育の授業では、メリハリをつけて素早く行動をする & 2.95 & .81 & .75 & .00 & .07 & -.12 & .04 & -.05 & -.01 \\
\hline 体育の授業では、準備・片付けをしっかりと行う & 3.33 & .78 & .74 & -.14 & .04 & -.10 & .01 & .00 & .01 \\
\hline 体育の授業では、ふざけることなく真剣に取り組む & 3.05 & .84 & .63 & .03 & -.03 & .08 & -.03 & -.01 & .12 \\
\hline 体育の授業では、準備運動を入念に行う & 3.22 & .81 & .62 & -.09 & -.10 & .01 & .12 & -.03 & .21 \\
\hline 体育の授業では、ケガをしないように気をつける & 3.29 & .83 & .48 & .05 & -.12 & .22 & -.05 & .07 & .04 \\
\hline 体育の授業では、整理運動を入念に行う & 2.69 & 1.03 & .47 & -.02 & .07 & .06 & .02 & -.03 & .22 \\
\hline \multicolumn{10}{|l|}{ II 仲間との協力的な取り組み $(\alpha=.80)$} \\
\hline 体育の授業では、仲間にアドバイスをする & 2.75 & .95 & .00 & .79 & -.14 & -.02 & .01 & .02 & .07 \\
\hline 体育の授業では、責任をもって自分に与えられた役割を果たす & 3.05 & .81 & -.12 & .78 & -.01 & .04 & -.05 & .01 & .01 \\
\hline $\begin{array}{l}\text { 体育の授業では、仲間同士やグループでの話し合いに参加しないことがあ } \\
\text { る※ }\end{array}$ & 1.88 & 1.01 & -.03 & .57 & .11 & .00 & .00 & -.05 & .19 \\
\hline 体育の授業では、仲間が失敗をしたら責めることがある※ & 1.91 & 1.05 & -.02 & .49 & .17 & .05 & .06 & .05 & -.07 \\
\hline 体育の授業では、仲間にアドバイスをもらう & 2.90 & .90 & -.05 & .46 & -.11 & -.06 & .01 & .01 & .10 \\
\hline \multicolumn{10}{|l|}{ III＼cjkstart楽しさの創出 $(\alpha=.81)$} \\
\hline 体育の授業では、何事に対してもつまらないと思わないようにする & 2.82 & .92 & -.03 & -.07 & .91 & .00 & -.01 & .00 & -.01 \\
\hline $\begin{array}{l}\text { 体育の授業では、興味や関心がないことに対しても、楽しく取り組むため } \\
\text { の工夫をする }\end{array}$ & 2.83 & .88 & -.06 & .07 & .73 & .08 & -.12 & .02 & .00 \\
\hline 体育の授業では、何事も楽しむことを心がける & 3.09 & .87 & .03 & -.06 & .68 & .00 & .07 & .01 & .08 \\
\hline 体育の授業では、みんなが楽しく取り組める䨌囲気をつくる & 3.07 & .87 & .11 & .26 & .54 & -.12 & .04 & -.08 & -.01 \\
\hline \multicolumn{10}{|l|}{ IV 挑戦的な取り組み $(\alpha=.79)$} \\
\hline 体育の授業では、何事にもあきらめずに取り組む & 3.11 & .84 & .00 & .04 & .01 & .85 & -.11 & -.03 & -.04 \\
\hline 体育の授業では、自分ができることでもさらなる上達を目指して取り組む & 3.14 & .83 & -.05 & .06 & -.07 & .71 & .07 & -.01 & .04 \\
\hline 体育の授業では、できるようになるまで練習をする & 2.70 & .87 & .11 & -.08 & .09 & .67 & .10 & .00 & -.08 \\
\hline \multicolumn{10}{|l|}{$\mathrm{V}$ 公正な取り組み $(\alpha=.79)$} \\
\hline 体育の授業では、運動やスポーツのマナーを守りながら取り組む & 3.29 & .78 & .10 & -.06 & -.10 & -.08 & .84 & .04 & .00 \\
\hline 体育の授業では、運動やスポーツのルールを正確に理解しようとする & 2.94 & .86 & -.11 & .01 & .04 & -.02 & .77 & .01 & .03 \\
\hline $\begin{array}{l}\text { 体育の授業では、仲間がよいパフォーマンスを見せたときには賞賛をする } \\
\text { (ほめる) }\end{array}$ & 3.22 & .87 & -.06 & .01 & .04 & .18 & .62 & -.08 & .01 \\
\hline 体育の授業では、運動やスポーツのルールを守りながら取り組む & 3.34 & .75 & .03 & .35 & -.03 & .00 & .43 & -.05 & -.06 \\
\hline \multicolumn{10}{|l|}{$\mathrm{VI}$ 教師への関わり $(\alpha=.80)$} \\
\hline 体育の授業では、先生が話しをしている時は先生の方を見て話しを聞く & 3.40 & .75 & .03 & .05 & -.05 & -.09 & -.03 & .91 & .00 \\
\hline $\begin{array}{l}\text { 体育の授業では、自分のパフォーマンスのできばえについて、先生にチェ } \\
\text { ックをしてもらう }\end{array}$ & 2.71 & .94 & .00 & -.02 & .03 & .00 & .10 & .61 & .00 \\
\hline 体育の授業では、わからないことがあったら先生に質問をする & 2.77 & .95 & .01 & .02 & .14 & .14 & -.05 & .52 & .01 \\
\hline 体育の授業では、できないことがあったら先生に質問をする & 2.77 & .93 & .16 & .03 & .19 & -.04 & .02 & .43 & .05 \\
\hline \multicolumn{10}{|l|}{ VII 思考・判断 $(\alpha=.72)$} \\
\hline 体育の授業では、うまくいかないときは原因や理由を考えながら取り組む & 2.94 & .87 & .03 & .05 & -.10 & -.01 & .00 & .06 & .81 \\
\hline 体育の授業では、他者のパフォーマンスを見て参考にする & 3.08 & .87 & .06 & .19 & .04 & -.08 & .01 & -.03 & .75 \\
\hline 体育の授業では、自分にあった練習のしかたを考える & 2.77 & .93 & .17 & .06 & -.01 & .00 & .06 & .02 & .50 \\
\hline 体育の授業では、自分にあった体の動かしかたを考えながら取り組む & 2.93 & .86 & .02 & -.07 & .10 & .20 & .09 & .05 & .43 \\
\hline
\end{tabular}


さを創出しようとする項目が示されていることか ら,「楽しさの創出」と命名した．第 4 因子は,「体 育の授業では，何事にもあきらめずに取り組む」 や「体育の授業では，自分ができることでもさら なる上達を目指して取り組む」などの項目を含み, 学習に対する挑戦的な取り組みに関する項目が示 されていることから，「挑戦的な取り組み」と命 名した．第 5 因子は，「体育の授業では，運動や スポーツのマナーを守りながら取り組む」や「体 育の授業では，運動やスポーツのルールを正確に 理解しようとする」などの項目を含み，運動やス ポーツに対する公正な取り組みに関する項目が示 されていることから，「公正な取り組み」と命名 した．第 6 因子は，「体育の授業では，先生が話 しをしている時は先生の方を見て話しを聞く」や 「体育の授業では，自分のパフォーマンスのでき ばえについて，先生にチェックをしてもらう」な どの項目を含み，教師への関わりに関する項目が 示されていることから，「教師への関わり」と命 名した. そして，第 7 因子は，「体育の授業では， うまくいかないときは原因や理由を考えながら取 り組む」や「体育の授業では, 他者のパフォーマ ンスを見て参考にする」などの項目を含み, 思考・ 判断に関する項目が示されていることから，「思 考・判断」と命名した.

続いて，尺度の内的一貫性を検討するため，上 記の 7 因子について，信頼性係数として Cronbach の $\alpha$ 係数を算出した. その結果, 第 1 因子 は $\alpha=.82$ ，第 2 因子は $\alpha=.80$, 第 3 因子は $\alpha=$ .81 , 第 4 因子は $\alpha=.79$, 第 5 因子は $\alpha=.79$, 第 6 因子は $\alpha=.80$, 第 7 因子は $\alpha=.72$ であった. いずれの因子も，.70 以上の $\alpha$ 係数が算出されて おり，一定程度の内的一貫性があることが確認さ れた。

なお，本研究では，開発した尺度を「中学生用 体育学習方略尺度（以下「体育学習方略尺度」と 略す)」と命名した。

\section{3. 再検査法による信頼性の検証}

各尺度の時間的安定性を検討するために，全調 査対象者のうち, 1 回目と 2 回目の回答の照合が
できた 666 名について，再検査法による信頼性 係数を算出した。その結果， 2 回の調査の得点に ついて, 体育学習観尺度では $r=.71$ から $r=.82$, 体育学習方略尺度では $r=.71$ から $r=.83$ の相関 係数が得られ，十分な時間的安定性が認められ た.したがって，両尺度は短期間の時間的要因に よる変動が少なく，安定性の観点からも高い信頼 性を有した尺度であると判断できる。

\section{4. 妥当性の検証}

尺度の妥当性を検証するため，各尺度の下位尺 度について，体育授業の好き嫌いを「好き」・「ど ちらでもない」・嫌い」の3つに分けて，1要因 の分散分析を行った（表 3).

その結果，体育学習観尺度では，「運動技術 の習得」 $(F(2,2438)=35.59, p<.001), 「 コ ミ ュ$ ニケーション能力の涵養」 $(F(2,2438)=40.74, p$ $<.001)$, 「身体と運動に関する知識の修得」 $(F$ $(2,2438)=29.55, p<.001)$, 「運動の魅力の感受」 $(F$ $(2,2438)=70.01, p<.001), 「$ 身体能力の向上」 $(F$ $(2,2438)=25.53, p<.001 ）$ に扔いて有意な主効果 が認められた．多重比較の結果，いずれも「どち らでもない」・嫌い」よりも「好き」の得点が有 意に高かった $(p<.001)$ ．また，「運動の魅力の 感受」,「身体能力の向上」において，「嫌い」よ りも「どちらでもない」の得点が有意に高かった $(p<.01)$.

次に, 体育学習方略尺度では, 「学習規律の重視」 $(F(2,2438)=25.51, p<.001) ， 「$ 仲間との協力的な 取り組み」 $(F(2,2438)=31.68, p<.001)$,「楽しさ の創出」 $(F(2,2438)=56.91, p<.001)$ ，「挑戦的な 取り組み」 $(F(2,2438)=50.68, p<.001)$ ，「公正な 取り組み」 $(F(2,2438)=27.24, p<.001)$,「教師へ の関わり」 $(F(2,2438)=36.26, p<.001)$, 「思考 · 判断」 $(F(2,2438)=32.07, p<.001)$ において有意 な主効果が認められた。多重比較の結果，いずれ も「どちらでもない」・嫌い」よりも「好き」の 得点が有意に高かった $(p<.001)$. また, 「楽し さの創出」、「挑戦的な取り組み」,「教師への関わ り」において，「嫌い」よりも「どちらでもない の得点が有意に高かった $(p<.01)$. 
表 3 体育授業の好き嫌いによるちがい

\begin{tabular}{|c|c|c|c|c|c|c|c|c|c|}
\hline & & \multicolumn{2}{|c|}{$\begin{array}{c}\text { 好き } \\
(N=1,681)\end{array}$} & \multicolumn{2}{|c|}{$\begin{array}{c}\text { どちらでも } \\
\text { ない } \\
(N=296)\end{array}$} & \multicolumn{2}{|c|}{$\begin{array}{c}\text { 嫌い } \\
(N=461)\end{array}$} & \multirow[t]{2}{*}{$F$ 值 } & \multirow[t]{2}{*}{ 多重比較 } \\
\hline & & $M$ & $S D$ & $M$ & $S D$ & $M$ & $S D$ & & \\
\hline \multirow{5}{*}{ 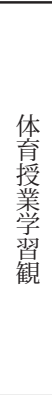 } & 運動技術の習得 & 3.17 & .62 & 2.77 & .63 & 2.65 & .69 & $35.59^{* * *}$ & 好き＞どちらでもない・嫌い \\
\hline & コミュニケーション能力の涵養 & 3.02 & .63 & 2.57 & .62 & 2.44 & .70 & $40.74^{* * *}$ & 好き>どちらでもない・嫌い \\
\hline & 身体と運動に関する知識の修得 & 3.14 & .61 & 2.80 & .59 & 2.72 & .62 & $29.55^{* * *}$ & 好き＞どちらでもない・嫌い \\
\hline & 運動の魅力の感受 & 3.29 & .64 & 2.72 & .63 & 2.34 & .74 & $70.01^{* * *}$ & $\begin{array}{c}\text { 好き>どちらでもない・嫌い } \\
\text { どちらでもない>嫌い }\end{array}$ \\
\hline & 身体能力の向上 & 3.06 & .66 & 2.79 & .62 & 2.56 & .74 & $25.53^{* * *}$ & $\begin{array}{c}\text { 好き>どちらでもない・嫌い } \\
\text { どちらでもない>嫌い }\end{array}$ \\
\hline \multirow{7}{*}{$\begin{array}{l}\text { 体 } \\
\text { 授 } \\
\text { 業 } \\
\text { 䏨 } \\
\text { 略 }\end{array}$} & 学習規律の重視 & 3.18 & .58 & 2.90 & .58 & 2.83 & .61 & $25.51^{* * *}$ & 好き>どちらでもない・嫌い \\
\hline & 仲間との協力的な取り組み & 2.68 & .55 & 2.37 & .54 & 2.27 & .54 & $31.68^{* * *}$ & 好き>どちらでもない・嫌い \\
\hline & 楽しさの創出 & 3.13 & .63 & 2.65 & .64 & 2.31 & .71 & $56.91^{* * *}$ & $\begin{array}{c}\text { 好き>どちらでもない・嫌い } \\
\text { どちらでもない>嫌い }\end{array}$ \\
\hline & 挑戦的な取り組み & 3.28 & .65 & 2.80 & .67 & 2.53 & .70 & $50.68^{* * *}$ & $\begin{array}{c}\text { 好き>どちらでもない・嫌い } \\
\text { どちらでもない>嫌い }\end{array}$ \\
\hline & 公正な取り組み & 3.30 & .61 & 2.95 & .63 & 2.93 & .66 & $27.24^{* * *}$ & 好き>どちらでもない・嫌い \\
\hline & 教師への関わり & 3.04 & .65 & 2.66 & .65 & 2.48 & .66 & $36.26^{* * *}$ & $\begin{array}{c}\text { 好き>どちらでもない・嫌い } \\
\text { どちらでもない>嫌い }\end{array}$ \\
\hline & 思考・判断 & 3.05 & .65 & 2.68 & .67 & 2.54 & .69 & $32.07^{* * *}$ & 好き>どちらでもない・嫌い \\
\hline
\end{tabular}

以上の結果から, 体育授業が好きな学習者ほど, 体育授業における学習観および学習方略を測定す る項目の得点が有意に高くなることが明らかにな った. このように, 両尺度ともに予測通りの結果 が得られたことから, 妥当性検証のための仮説は 支持されたものと考えられる.

\section{5. 因子不変性の検証}

尺度の因子構造の不変性を検証するため, 各尺 度の探索的因子分析の結果に基づき, 同一のデー タを用いた確認的因子分析を行った。

まず，体育学習観尺度について，5つの潜在因 子からそれぞれ該当する項目が影響を受け, 全て の因子間に共分散が存在することを仮定したモデ ルで分析を行った. その結果, モデルの適合度指 標は $\mathrm{GFI}=.91, \mathrm{AGFI}=.90, \mathrm{CFI}=.88, \mathrm{RMSEA}=$ .04 となり, CFIの值がやや低いものの, 良好な
適合度を示した.

次に, 体育学習方略尺度について，7つの潜在 因子からそれぞれ該当する項目が影響を受け, 全 ての因子間に共分散が存在することを仮定した モデルで分析を行った. その結果, モデルの適合 度は $\mathrm{GFI}=.92, \mathrm{AGFI}=.89, \mathrm{CFI}=.87, \mathrm{RMSEA}=$ .06 となり, 概ね許容される範囲の值を示した。

以上の結果から, 両尺度の因子不変性が確認さ れた.

\section{6. 各尺度の基本統計量と学年差・性差の検討}

体育学習観尺度および体育学習方略尺度の基本 統計量と学年差・性差を算出するために, 学年 (1 年生・ 2 年生・ 3 年生）と性（男子・女子）を要 因とする 2 要因の分散分析を行った（表 4).

まず，体育学習観尺度においては，いずれの 下位尺度においても交互作用が認められなかっ 
表 4 各尺度の基本統計量执よび学年差・性差

\begin{tabular}{|c|c|c|c|c|c|c|c|c|c|c|c|c|c|c|c|c|c|}
\hline & & \multicolumn{4}{|c|}{ (1)1 年生 $(N=769)$} & \multicolumn{4}{|c|}{ (2)2 年生 $(N=878)$} & \multicolumn{4}{|c|}{ (3)3 年生 $(N=791)$} & \multirow{2}{*}{\multicolumn{3}{|c|}{$F$ 值 }} & \multirow{3}{*}{ 多重比較 } \\
\hline & & \multicolumn{2}{|c|}{$\begin{array}{c}\text { 男子 } \\
(N=377)\end{array}$} & \multicolumn{2}{|c|}{$\begin{array}{c}\text { 女子 } \\
(N=392)\end{array}$} & \multicolumn{2}{|c|}{$\begin{array}{c}\text { 男子 } \\
(N=410)\end{array}$} & \multicolumn{2}{|c|}{$\begin{array}{c}\text { 女子 } \\
(N=468)\end{array}$} & \multicolumn{2}{|c|}{$\begin{array}{c}\text { 男子 } \\
(N=383)\end{array}$} & \multicolumn{2}{|c|}{$\begin{array}{c}\text { 女子 } \\
(N=408)\end{array}$} & & & & \\
\hline & & $M$ & $S D$ & $M$ & $S D$ & $M$ & $S D$ & $M$ & $S D$ & $M$ & $S D$ & $M$ & $S D$ & 学年 & 性別 & $\begin{array}{l}\text { 交互 } \\
\text { 作用 }\end{array}$ & \\
\hline \multirow{5}{*}{ 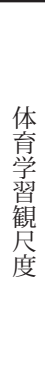 } & 運動技術の習得 & 2.93 & .70 & 2.89 & .66 & 3.12 & .63 & 3.08 & .67 & 3.14 & .64 & 3.13 & .60 & $14.59^{* * *}$ & .46 & .06 & $2 \cdot 3>1$ \\
\hline & $\begin{array}{c}\text { コミュニケーション } \\
\text { 能力の涵養 }\end{array}$ & 2.53 & .70 & 2.56 & .67 & 2.83 & .67 & 2.89 & .65 & 2.93 & .66 & 2.95 & .64 & 23.64 & .00 & .76 & $2 \cdot 3>1$ \\
\hline & $\begin{array}{c}\text { 身体と運動に関する } \\
\text { 知識の修得 }\end{array}$ & 2.95 & .63 & 2.87 & .62 & 3.07 & .62 & 3.04 & .65 & 3.12 & .64 & 3.19 & .57 & 16.12 & .11 & 1.47 & $\begin{array}{c}3>1, \quad 3>2 \\
2>1\end{array}$ \\
\hline & 運動の魅力の感受 & 2.95 & .79 & 2.91 & .74 & 3.13 & .74 & 3.16 & .72 & 3.19 & .71 & 3.19 & .69 & $15.54^{* * *}$ & .02 & .21 & $2 \cdot 3>1$ \\
\hline & 身体能力の向上 & 2.85 & .70 & 2.80 & .71 & 3.04 & .66 & 3.01 & .70 & 3.00 & .68 & 3.06 & .65 & $12.67^{*}$ & .08 & .71 & $2 \cdot 3>1$ \\
\hline \multirow{7}{*}{$\begin{array}{l}\text { 体 } \\
\text { 呅 } \\
\text { 習 } \\
\text { 略 } \\
\text { 度 }\end{array}$} & 学習規律の重視 & 2.92 & .60 & 3.01 & .62 & 3.12 & .51 & 3.18 & .63 & 3.18 & .60 & 3.16 & .59 & $15.05^{* * *}$ & 1.43 & .72 & $2 \cdot 3>1$ \\
\hline & $\begin{array}{c}\text { 仲間との協力的な } \\
\text { 取り組み }\end{array}$ & 2.46 & .64 & 2.31 & .55 & 2.61 & .54 & 2.44 & .53 & 2.73 & .55 & 2.48 & .54 & $11.53^{* *}$ & $6.75^{* *}$ & 2.27 & $\begin{array}{c}2 \cdot 3>1 \\
\text { 男子>女子 }\end{array}$ \\
\hline & 楽しさの創出 & 2.79 & .71 & 2.81 & .75 & 2.98 & .70 & 3.02 & .70 & 3.08 & .64 & 3.04 & .71 & 16.07 & .01 & .43 & $2 \cdot 3>1$ \\
\hline & 挑戦的な取り組み & 2.80 & .73 & 2.81 & .79 & 3.08 & .65 & 3.10 & .70 & 3.07 & .70 & 3.09 & .68 & $18.90^{* * *}$ & 1.00 & .12 & $2 \cdot 3>1$ \\
\hline & 公正な取り組み & 3.01 & .66 & 3.14 & .66 & 3.29 & .54 & 3.26 & .66 & 3.23 & .62 & 3.30 & .61 & 13.54 & 2.74 & 1.80 & $2 \cdot 3>1$ \\
\hline & 教師への関わり & 2.70 & .68 & 2.89 & .71 & 2.94 & .63 & 3.06 & .69 & 2.92 & .66 & 2.95 & .67 & $10.28^{* * *}$ & $8.22^{* *}$ & 1.28 & $\begin{array}{c}3>1,2>1 \\
\text { 女子>男子 }\end{array}$ \\
\hline & 思考 - 判断 & 2.76 & .71 & 2.77 & .71 & 3.01 & .62 & 3.01 & .71 & 3.05 & .65 & 3.03 & .66 & 20.67 & .01 & .09 & $2 \cdot 3>1$ \\
\hline
\end{tabular}

た。次に，主効果の検定を行ったところ，「運動 技術の習得」 $(F(2,2438)=14.59, p<.001), 「 コ ミ$ ユニケーション能力の涵養」 $(F(2,2438)=23.64$, $p<.001)$,「身体と運動に関する知識の修得」( F $(2,2438)=16.12, p<.001)$, 「運動の魅力の感受」 $(F$ $(2,2438)=15.54, p<.001), 「$ 身体能力の向上」 $(F$ $(2,2438)=12.67, p<.001)$ において学年の有意な 主効果が認められた。多重比較の結果，いずれの 下位尺度において, 1 年生よりも 2 年生・ 3 年生 の得点が有意に高く $(p<.001)$, 加えて「身体と 運動に関する知識の修得」においては，2 年生よ りも 3 年生の得点が有意に高かった $(p<.01)$. 性差はみられなかった。

続いて，体育学習方略尺度の下位尺度において も，交互作用は認められなかった。主効果の検定 を行ったところ,「学習規律の重視」( F $(2,2438)$ $=15.05, p<.001), 「$ 仲間との協力的な取り組み」
$(F(2,2438)=11.53, p<.001)$,「楽しさの創出」 $(F$ $(2,2438)=16.07, p<.001)$ ，「挑戦的な取り組み」 $(F(2,2438)=18.90, p<.001), 「$ 公正な取り組み」 $(F(2,2438)=13.54, p<.001), 「$ 教師への関わり」 $(F(2,2438)=10.28, p<.001), 「$ 思考・判断」 $(F$ $(2,2438)=20.67, p<.001)$ において学年の有意な 主効果がみられた．多重比較の結果，いずれの下 位尺度においても 1 年生よりも 2 年生・3 年生の 得点が有意に高かった。

また,「仲間との協力的な取り組み」( $F$ $(1,2438)=6.75, p<.01), 「$ 教師への関わり」 $(F$ $(1,2438)=8.22, p<.01)$ において性別による有意 な主効果がみられた。多重比較の結果，「仲間と の協力的な取り組み」では女子よりも男子の方が 有意に得点が高く,「教師への関わり」において は男子よりも女子の得点が有意に高かった. 


\section{7. 体育学習観と体育学習方略の関連}

体育学習観と体育学習方略の関連を明らかにす るために, 両尺度の相関係数を算出した. その結 果, 体育学習観尺度と体育学習方略尺度の各下位 尺度の全てにおいて, 弱一中程度の有意な正の相 関関係が認められた（表 5).

まず，「運動技術の習得」は，「仲間との協力的 な取り組み」 $(r=.54, p<.001)$,「楽しさの創出」 $(r$ $=.22, p<.01)$,「挑戦的な取り組み」 $(r=.29, p<$ $.001)$,「思考・判断」 $(r=.36, p<.001)$ との間に 有意な正の相関を示した.「コミュニケーション 能力の涵養」は, 「学習規律の重視」 $(r=.20, p<$ $.01)$,「仲間との協力的な取り組み」 $(r=.36, p<$ $.001)$, 「楽しさの創出」 $(r=.51, p<.001)$, 「挑戦 的な取り組み」 $(r=.22, p<.01)$,「公正な取り組み」 $(r=.32, p<.001)$, 「教師への関わり」( $r=.30, p<$ $.001)$,「思考・判断」 $(r=.21, p<.01)$ というように, 体育学習方略尺度の全ての下位尺度に有意な正の 相関を示した。「身体と運動に関する知識の修得」 は,「学習規律の重視」 $(r=.38, p<.001)$, 「公正 な取り組み」 $(r=.51, p<.001)$ に有意な正の相関 を示した.「運動の魅力の感受」は, 「楽しさの創出」 $(r=.33, p<.001), 「$ 挑戦的な取り組み」 $(r=.30$, $p<.001)$,「公正な取り組み」 $(r=.20, p<.01)$ に 有意な正の相関を示した. そして,「身体能力の 向上」は,「仲間との協力的な取り組み」 $(r=.18$, $p<.05)$ ，「挑戦的な取り組み」 $(r=.40, p<.001)$, 「思考・判断」 $(r=.25, p<.01)$ に有意な正の相関 を示した。

\section{IV 追加調査（基準関連妥当性の検証）}

\section{1. 目的}

追加調查の目的は, 「中学生用体育学習観尺度」 および「中学生用体育学習方略尺度」の基準関連 妥当性の検証を行い, 尺度の精緻化を図ることで ある。

\section{2. 方法}

\section{1. 調査時期・対象者および手続き}

調査は, 2017 (平成 29) 年 9 月に, 東京都の 3 校の公立中学校において実施した。内訳は, 中学 校 1 年生から 3 年生の計 287 名（男子 135 名, 女 子 152 名）であった. そのうち, 記入漏れや記入 ミスのあったものを除き, 有効回答者 263 名（男 子 127 名, 女子 136 名）を分析の対象とした. 調 査の手続きは, 調査対象者の在籍する学級単位で 授業時間を用いて集団で実施された。なお，全て の学級が, 男女別習で授業を行っていた.

\section{2. 倫理的配慮}

質問紙調査は無記名式で行い, 調査対象者の回 答の匿名性が確保されることを質問紙に明記し た. 調査に対する同意については, 質問への回答 は自由意志であること, 答えられない項目や, 答 えたくない項目は無理に答えなくてよいことを質 問紙に明記することによって得られたものと判断 された。

表 5 中学生の体育学習観と体育学習方略の関連

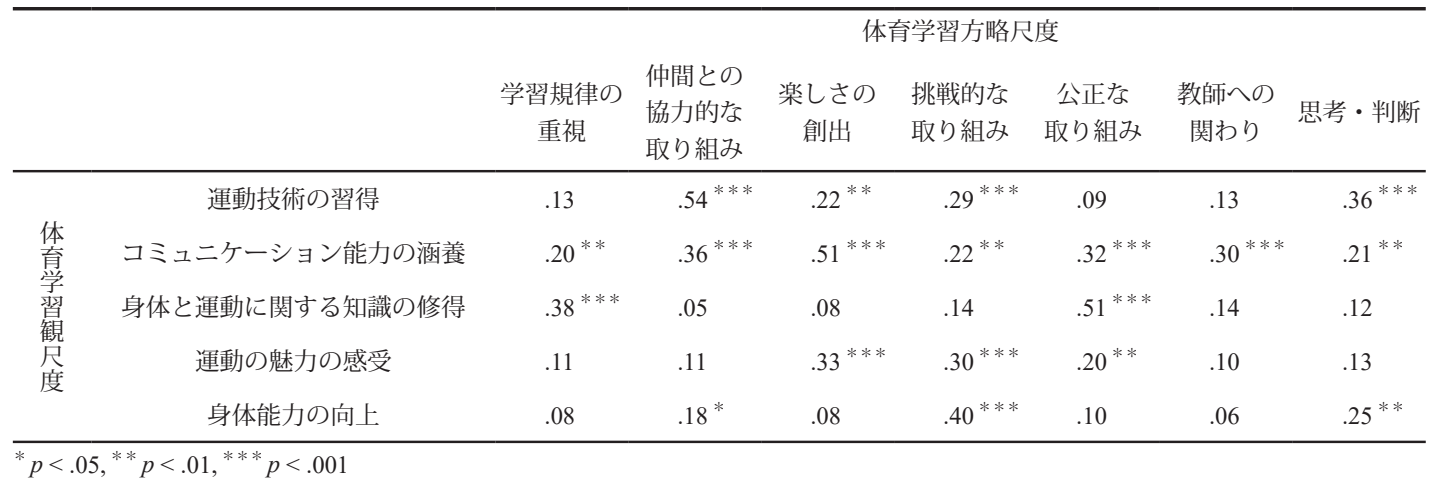




\section{3. 調査内容}

\section{1）「中学生用体育学習観尺度」}

本研究で開発した「中学生用体育学習観尺度」 （22 項目）を用いた.「よくあてはまる（4 点）」, 「あてはまる（3 点)」, 「少しあてはまる（2 点）」, 「全然あてはまらない（1 点)」の 4 件法で回答を 求めた.

\section{2）「中学生用体育学習方略尺度」}

本研究で開発した「中学生用体育学習方略尺度」 （30 項目）を用いた.「よくあてはまる（4 点）」, 「あてはまる（3 点)」, 「少しあてはまる（2 点）」, 「全然あてはまらない（1 点)」の 4 件法で回答を 求めた.

\section{3）「授業評価尺度」（診断的・総括的授業評価）}

基準関連妥当性を検証するための尺度として, 高田ほか（2000）が開発した「授業評価尺度（中 学生用)」を用いた。この尺度は,「診断的・総括 的授業評価」と呼ばれ，体育の授業改善のための フィードバック情報を得ることを目的として開発 された。「体育では，いろいろな運動が上手にで きるようになります」や「体育で，ゲームや競 争をするときは, ルールを守ります」など, 計 20 項目から構成されており，「たのしむ」，「でき る」,「まなぶ」,「まもる」の 4 因子構造である（高
田ほか, 2000). Cronbachの $\alpha$ 係数は.60 から.75 を算出しており，一定程度の信頼性が確認されて いる，実施に際しては，「はい（3 点）」,「どちら でもない（2点）」,「いいえ（1点）」の 3 件法で 回答を求めた。

授業評価尺度は, 学習者の体育授業に対する学 習観や学習方略に焦点を当てた尺度ではない。し かしながら, 尺度全体を通して学習者の体育授業 に対する価值観や学習態度を問う項目で構成され て抢り，こうした傾向が，本研究で開発した2つ の尺度と類似している. すなわち, 授業評価尺度 の下位尺度には，体育授業に対する学習観や学習 方略に関連する項目が散見され，それらが混在し ながら因子を形成している。こうした点に鑑みれ ば，授業評価尺度の下位尺度は，体育学習観尺度 と体育学習方略尺度の各下位尺度と有意な正の相 関を示すことが予測される。

\section{3. 結果}

体育学習観尺度・体育学習方略尺度と授業評価 尺度の間で相関分析を行った。その結果, 体育学 習観尺度と体育学習方略尺度ともに, 授業評価尺 度の各下位尺度と弱一中程度の有意な正の相関関 係 $(r=.20-.67)$ が認められた（表 6).

表 6 体育学習観尺度 - 体育学習方略尺度と授業評価尺度の相関分析結果

\begin{tabular}{|c|c|c|c|c|c|}
\hline & & \multicolumn{4}{|c|}{ 授業評価尺度 } \\
\hline & & たのしむ & できる & まなぶ & まもる \\
\hline \multirow{5}{*}{ 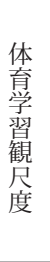 } & 運動技術の習得 & .14 & $.67^{* * *}$ & .16 & $.55^{* * *}$ \\
\hline & コミュニケーション能力の涵養 & $.27^{* *}$ & $.49^{* * *}$ & $.22 * *$ & $.58^{* * *}$ \\
\hline & 身体と運動に関する知識の修得 & $.30^{* * *}$ & .10 & $.32^{* * *}$ & .06 \\
\hline & 運動の魅力の感受 & $.63^{* * *}$ & .17 & $.35^{* * *}$ & $.22^{* *}$ \\
\hline & 身体能力の向上 & $.20^{* *}$ & $.50 * * *$ & $.24^{* *}$ & $.35^{* * *}$ \\
\hline \multirow{7}{*}{$\begin{array}{l}\text { 体 } \\
\text { 掌 } \\
\text { 習 } \\
\text { 略 } \\
\text { 度 }\end{array}$} & 学習規律の重視 & .16 & .15 & $.32 * * *$ & $.34^{* * *}$ \\
\hline & 仲間との協力的な取り組み & .17 & $.51^{* * *}$ & $.38^{* * *}$ & $.36^{* * *}$ \\
\hline & 楽しさの創出 & $.33^{* * *}$ & $.21^{* *}$ & .06 & $.54^{* * *}$ \\
\hline & 挑戦的な取り組み & $.34^{* * *}$ & $.40^{* * *}$ & .15 & $.21^{* *}$ \\
\hline & 公正な取り組み & $.25^{* *}$ & .12 & $.30^{* * *}$ & $.58^{* * *}$ \\
\hline & 教師への関わり & .13 & .11 & $.25^{* *}$ & .17 \\
\hline & 思考·判断 & .16 & $.34^{* * *}$ & $.25^{* *}$ & $.23 * *$ \\
\hline
\end{tabular}


その中でも, 体育学習観尺度では, 「運動技術 の習得」が「できる」 $(r=.67, p<.001), 「 コ ミ ュ$ ニケーション能力の涵養」が「まもる」 $(r=.58$, $p<.001)$,「身体と運動に関する知識の修得」が「ま なぶ」 $(r=.32, p<.001), 「$ 運動の魅力の感受」が 「たのしむ」 $(r=.63, p<.001)$,「身体能力の向上」 が「できる」 $(r=.50, p<.001)$ と，それぞれ最も 強い有意な正の相関を示した。

次に, 体育学習方略尺度では, 「学習規律の重視」 が「まもる」 $(r=.34, p<.001)$, 「仲間との協力的 な取り組み」が「できる」 $(r=.51, p<.001)$,「楽 しさの創出」が「まもる」 $(r=.54, p<.001)$,「挑 戦的な取り組み」が「できる」 $(r=.40, p<.001)$,「公 正な取り組み」が「まもる」 $(r=.58, p<.001)$,「教 師への関わり」が「まなぶ」 $(r=.25, p<.01)$,「思 考・判断」は「できる」 $(r=.34, p<.001)$ と, そ れぞれ最も強い有意な正の相関を示した.

\section{$\mathrm{V}$ 考 察}

本研究の目的は, 「中学生用体育学習観尺度」 および「中学生用体育学習方略尺度」を開発し, その学年差・性差, そして, 中学生の体育授業に おける学習観と学習方略の関連を明らかにするこ とであった。

\section{中学生の体育学習観尺度の因子構造について}

まず, 中学生の体育授業における学習観の因子 構造を検討するため, 探索的因子分析を実施し た. その結果,「中学生用体育学習観尺度」は, 「運動技術の習得」,「コミュニケーション能力の 涵養」,「身体と運動に関する知識の修得」,「運動 の魅力の感受」「「身体能力の向上」という 5 因子, 計 22 項目から捉えられることが明らかになった.

体育学習観尺度を構成する諸因子からは, 体育 の教科内容領域注 2) と類似した傾向が示された. すなわち,「運動技術の習得」は, 運動やスポー ツの個人的・集団的な運動技術の習得に関わる「技 術学習」に対応する.「コミュニケーション能力 の涵養」は, 運動やスポーツの規範的・価值的内 容や態度形成に関わる「社会学習」に,「身体と
運動に関する知識の修得」は, 体育の科学的知識 に関わる「認識学習」に,「運動の魅力の感受」は, 運動やスポーツへの嗜好性や愛好性の育成に関わ る「情意学習」に対応していると考えられる.

そして，これら 4 因子に加えて「身体能力の向 上」が抽出された. 現行の学習指導要領におい て身体形成は, 各運動領域を「学習した結果と してょり一層の体力の向上を図ることができる よう」（文部科学省，2008，p.4）にするとしてい る.これ自体は, 体づくりや体力の向上などの身 体形成が, 各運動領域の技術学習の結果において なされるとする立場を表しているという（友添, 2010). しかしながら, 学習者の立場からすれば, 「身体能力の向上」は「運動技術の習得」から独 立したものと捉えられており, 両者は切り離して 考えられていることがわかった.

以上から, 体育において教えるべき教科内容と 学習者の学習観に, 大きな相違はなかったことが 明らかになった，換言すれば，本尺度を用いるこ とによって, 教師が教えようとしている内容を, 実際に学習者がどの程度学び取っているのかを測 ることができるともいえよう.

\section{中学生の体育学習方略尺度の因子構造について}

続いて, 中学生の体育授業における学習方略の 因子構造を検討するため, 探索的因子分析を実施 した. その結果, 「中学生用体育学習方略尺度」は, 「学習規律の重視」,「仲間との協力的な取り組み」, 「楽しさの創出」,「挑戦的な取り組み」,「公正な 取り組み」,「教師への関わり」,「思考・判断」と いう 7 因子, 30 項目から捉えられることが明ら かになった。

抽出された 7 因子にそれぞれ着目してみると, 1つ目に「よい体育授業のための基礎的条件」(高 橋・岡澤, 1994, p.18）にも挙げられている「学 習規律の重視」が抽出された. 高橋・岡澤（1994） によれば, 体育授業において学習規律は, 教師自 身の「権威」によって維持することもできるもの の, そこから肯定的な授業の䨌囲気を生み出すこ とや意欲的な学習態度を引き出すことは難しいと されている。こうした意味からも, 教育実践にお 
いては，ここで見出された学習規律に関わる各項 目が，学習者の自発的な行動によって向上してい くことが望まれる.

2つ目に，こちらも「よい体育授業のための基 礎的条件」（高橋・岡澤，1994，p.18）に挙げら れている「仲間との協力的な取り組み」が抽出さ れた.ここでは, 教え手と学び手の両立場に関わ る項目が含まれており, 一般的な学習方略でいう ところの「援助要請方略」に相当する因子である と考えられる.こうした仲間同士での教えあい注3 には，単にわからないことを教えてもらうという 外的リソースとしての他者活用以外に, 他者に教 えることで自身の理解状態を的確に把握すること ができるなど，教え手と学び手の両方に学習効果 があることが報告されている（Cohen et al., 1982； 市川，2000)。また，ここでは他者との調和を図 る項目も含まれていることから, 学習者は, 他者 への配慮も重視していることがわかる.

3つ目に, 楽しさを学習者自身で見出していく 「楽しさの創出」が抽出された，従来，体育学習 における「楽しさ」の位置づけをめぐっては, 高橋・ 岡澤 (1994) の「体育の具体的目標の構造」(高橋・ 岡澤，1994，p.13）によって示されたモデルが広 く理解されてきた.すなわち，「運動技術の学習 に関連して運動技能や体力の目標が導かれ，社会 的行動の学習に関連して, 社会的態度の目標が, 認知的・反省的学習に関連して, 思考・判断や理 解の目標が導かれる」(高橋・岡澤, 1994, p.13) ものとされてきた. そして, これらの学習の結果 として,「情意学習」に関わる情意的目標（楽し さの体験）がもたらされるという（高橋・岡澤, 1994). しかし, 本研究では, 体育における楽し さを学習者が学習方略の 1 つとして意図的に見出 していることが明らかになり，これ自体は，高橋 らが掲げるモデルとは異なる構図を示している. こうした本研究の知見を踏まえれば, 楽しさの生 起の仕方については, 今後さらなる詳細な検討が 必要である.

4つ目に，できるようになるために反復的に練 習に取り組む「挑戦的な取り組み」が抽出された. これは，一般的な学習方略でいうところの「リハ
一サル方略」に類似するものと考えられる。「リ ハーサル方略」とは, 学習内容を覚えるために, 繰り返し暗唱したり, 反復して記述することなど を示す方略であり（瀬尾ほか，2008），多くの学 習方略尺度に現れる。特に体育では，ドリルゲー ムや慣れの運動などが多く取り入れられているこ とから，こうした取り組みもまた，挑戦的な取り 組みを強く意識づけていくものと考えられる.

5つ目に，運動・スポーツのルールやマナーを 遵守しながら取り組む「公正な取り組み」が抽出 された，体育では，ルールの厳守や他者に対する マナーの配慮，またフェアプレーが求められる場 面が随時に存在し，これ自体は体育特有の学習環 境であるといえる.

6つ目に,「教師への関わり」が抽出された. これは，一般的な学習方略でいうところの「援助 要請方略」に相当する因子であると考えられる. これまで, 教師の肯定的な働きかけが，よい体育 授業のための基礎的条件とされてきたが（高橋・ 岡澤, 1994), 本研究の結果から, 改めて援助要 請というものが, 教師側の働きかけだけではなく, 学習者と教師の対人的相互行為によって成り立っ ていることを認識することができる，ただし，安 易な解決手段として, 教師に依存的な援助要請を する学習者の存在も指摘されていることから（瀬 尾，2008）, 教師もまた，単に「よい」ものとし て教師への関わりを促すのではなく, 学習者の援 助要請の仕方に注意しながら対応していく必要が ある。

7つ目に，「思考・判断」は，一般的な学習方 略でいうところの「理解モニタリング方略」に類 似する因子であると考えられる。「理解モニタリ ング方略」は，メタ認知的活動の 1 つであり，自 身の認知過程に関する知識や，その認知過程を組 織化・監視・修正する活動を表す概念である（瀬 尾ほか，2008）。学習者は, 体の動かし方や，う まくいかない原因などについて思考し, 自身のパ フォーマンスなどへの理解を深めながら取り組ん でいるといえよう.

以上のように, 体育学習方略尺度の 7 因子から は，一般的な学習方略尺度で指摘される各方略だ 
けではなく, 体育特有の学習方略が見出された. すなわち,「公正な取り組み」や「楽しさの創出」 は他の学習方略尺度ではみられないこと, また, 内容的にも体育授業の特徴を反映していると判断 できることから，これらは体育特有の学習方略で あると考えられる。

また, 本尺度の因子構造は, 伊藤 (2001）が開 発した尺度 (「一般学習方略」,「めあて方略」,「努 力調整方略」）と大きく異なる。これは, 尺度の 開発方法の違いが影響した可能性がある. 先述し たように，伊藤（2001）は既存の尺度から体育の 学習場面に関連が深いと考えられる項目を選び, 体育に合わせて表現を修正した項目を用いた。そ れに対して, 本研究では, 自由記述による予備調 査から項目を収集・精選した. 体育特有の因子を 抽出するという狙いに鑑みても, 本研究が用いた 尺度の開発方法は有効的であったと考える.

\section{学年差・性差について}

まず, 学年差の検討では, 体育学習観尺度と体 育学習方略尺度の全ての因子で, 1 年生よりも 2 ・ 3 年生の方が有意に高かった. Pintrich and Zusho （2002）によれば, 学習に対するメタ認知や学習 方略の使用は, 学習を積み重ねた結果, 増加する ものとされている. その背景として, 一般的に学 習課題は, 学年が上がるほどに量的・質的に難し くなることから, 学習者は自身の理解状態を自己 監視やコントロールするなどのメタ認知活動を多 く行わなければならないことが指摘されている。 中学校の体育の場合, 1 年生と 2 年生の学習内容 は同じとされているものの（文部科学省，2008）, 1 年生はまだ小学校の延長線上にあることが想定 されること, また, 学習内容の定着度にも違いが 生じていることが考えられる.このことからも, 中学校の体育においてもまた, 学年段階に伴う学 習の積み重ねの差が, 学習方略使用の複雑化をも たらすことが推察される.

続いて, 性差に関する検討では, 体育学習方略 尺度において, 男子の方が仲間と協力的に取り組 んでいることがわかった. しかし, 一般的な学習 活動における仲間関係の特徴を明らかにした岡
田（2008）の研究によれば, 男子よりも女子の方 が仲間への援助要請・提供や, 仲間との相互学習 に積極的に取り組むことが報告されている. 岡田 （2008）の研究では, 身体活動を伴う学習場面は 想定されていないことから, 男子は身体活動を伴 った場合において, 仲間との協力的な取り組みが 促進される傾向にあるといえよう。これ自体は, 体育特有の学習可能性を示していると考えられ る.

一方で, 女子は男子よりも積極的に教師と関わ ることがわかった. 藤田（2012）の研究によれ ば, 中学生の体育において, 運動の仕方がわから ない時や上手くできない時は, 女子の方が積極的 に教師に質問し, 助言を求める傾向にあることが 報告されている. 本研究で見出した「教師への関 わり」も,このことに類似した結果が示されたと 考える.ただし, 教師への関わりの強さや頻度に ついては, 教師側の諸要因も影響していると推察 される.この点については本研究で詳しく検討す ることができないため, 今後, どのような教師側 の要因が, 学習者の教師への関わりを促進するの かも検討していく必要があるだろう.

\section{体育学習観と体育学習方略の関連について}

続いて, 体育学習観と体育学習方略の関連につ いて，相関分析を用いて検討した.

まず，体育を「運動技術を習得」する学習だと 考えている学習者は, 「仲間との協力的な取り組 み」を重視する傾向にあることが明らかになっ た. その一方で,「教師への関わり」との相関関 係は示されなかった. この結果から, 学習者は運 動技術の習得にあたって, 教師に直接的に指導し てもらうよりも, 仲間同士での協力的な取り組み の中で運動技術の習得を図ろうとしていることが 示唆される. 本研究では, 教師一学習者間の関係 性を詳細に検討しているわけではないために速断 はできないが, 少なくとも学習者は仲間同士の関 係性の中で, 運動技術の習得に励むという行動的 特徴が示唆されたといえよう. それに加えて, 運 動技術の習得は, 「楽しさの創出」,「挑戦的な取 り組み」,「思考・判断」とも弱い有意な正の相関 
関係が認められた。運動技術の習得にあたっては, 思考・判断を重ねつつ, 反復的かつ向上心を伴つ た挑戦的な取り組みがなされるとともに，どのよ うな状況においても，取り組みの中に楽しさを見 出そうとしている状況を窥い知ることができる.

体育を「コミュニケーション能力を涵養」する 学習だと考えている学習者は, 多彩な学習方略を 使用していることが明らかになった.「仲間」や「教 師」といった人間関係を直接的に表す学習方略以 外とも関連が見出された点が特徴的であり, ルー ルやマナーを守り, かつ真摰に取り組むことがコ ミュニケーション能力の涵養につながっているこ とが示唆される. 特に,「楽しさの創出」と最も 強い相関関係を示した点からは, 楽しさを見出す ことが決して学習者自身のためだけに行われてい るわけではなく，他者と調和を図るための方略と しても位置づいていることが窥える.これ自体は, グループやチームでの学習機会が多い体育特有の 同調的な傾向を示していると考えられる.

体育を「身体と運動に関する知識を修得」する 学習だと考えている学習者は, 「学習規律」や「教 師への関わり」「公正な取り組み」を重視してい ることが明らかになった。これは, 運動・スポー ツのルールやマナー, あるいは運動・スポーツの 意義を学んでいるからこそ, 実際の活動場面にお いて, 公正な取り組みや学習規律が重要であるこ とを認識していると考えられる.

体育を「運動の魅力を感受」する学習だと考え ている学習者は,「楽しさの創出」や「挑戦的な 取り組み」「公正な取り組み」を重視しているこ とが明らかになった。これは, 運動によって得ら れる楽しさや喜びを理解しているからこそ，それ を実体験するため，あきらめずに取り組むことな ど，向上心を伴った行動に向かうものと考えられ る. また, 運動時のルールやマナーをよく理解す ることが, 実際の行動へとつながっていることも 示している.

最後に, 体育を「身体能力の向上」を図る学習 だと考えている学習者は,「挑戦的な取り組み」 を重視する傾向にあることが明らかになった．持 久力や筋力をはじめとする様々な身体能力が, 反
復的な取り組みや練習によって向上することは周 知のとおりであるが, 体育の学習場面においても, こうした認識と実際の行動との関連の強さが示唆 された．また，それだけではなく，あきらめずに できるようになるまで取り組むなど，いわば「向 上心」を伴った行動によって支えられていること も窥える．さらに，弱い有意な正の相関関係では あるものの,「仲間との協力的な取り組み」や「思 考・判断」との関係が示されたことからは, こう した取り組みが, 個人内にとどまらず, 仲間と協 力しながら行われていること，さらには，思考・ 判断を重ねながら得られるものであると理解され ていると考えられる.

全体を通して見てみると, 体育学習観の中では, 「コミュニケーション能力の涵養」が最も多くの 学習方略との関連を示した.このことから, 学習 者に対してコミュニケーション能力の涵養を体育 の学習観として意識づけることは, 学習者の多彩 な学習方略使用の促進にもつながっていくと考え られる.

一方で，体育学習方略においては，「挑戦的な 取り組み」が最も多くの学習観との関連を示し た。これ自体は決して体育特有の学習方略ではな いものの，運動の技能を身につけることが教科目 標とされる体育では, 特に重要な学習方略として 位置づけられるといえよう。

\section{両尺度の基準関連妥当性について}

両尺度の精緻化を図るために追加調査を実施 し，基準関連妥当性を検証した。先述したよう に，高田ほか（2000）が開発した授業評価尺度の 下位尺度には，学習者の体育授業に対する学習観 や学習方略に関連する項目が散見される．そのた め, 本研究で開発した尺度と授業評価尺度の下位 尺度との間で, 多くの有意な正の相関関係が示さ れた，そこで，以下では，基準関連妥当性の検証 として, 本研究で開発した両尺度の下位尺度が授 業評価尺度のどの下位尺度と最も強い相関関係を 示したのかという点に焦点を当てて考察する.

まず，体育学習観尺度において，「運動技術の 習得」と「身体能力の向上」が最も強い相関関 
係を示したのが，「できる」であった。「できる」 は，学習者の技術習得に関わる項目で構成されて おり，「運動技術の習得」と中程度の有意な正の 相関関係を示したことは妥当な結果であると考え られる．また，「身体能力の向上」も「できる」 が示すような運動の上達に関わることから, 中程 度の有意な正の相関関係を示したものと考えられ る.

「コミュニケーション能力の涵養」が最も強い 相関関係を示したのは,「まもる」であった。「ま もる」は, 学習者の体育授業場面での社会的行動 を示しており, 社会学習に関わる「コミュニケー ション能力の涵養」と中程度の有意な正の相関関 係を示したことは, 妥当な結果であると考えられ る.

「身体と運動に関する知識の修得」が最も強い 相関関係を示したのは,「まなぶ」であった。「ま なぶ」は, 学習者の知識の修得や学習過程での知 的な関わりを示しており, 認識学習に関わる「身 体と運動に関する知識の修得」と弱いながらも有 意な正の相関関係が示されたことは，概ね妥当な 結果であると考えられる.

「運動の魅力の感受」が最も強い相関関係を示 したのは,「たのしむ」であった.「たのしむ」は, 運動学習に伴う情意面を示しており, 情意学習に 関わる「運動の魅力の感受」と中程度の有意な正 の相関関係が示されたことは, 妥当な結果である と考えられる.

次に, 体育学習方略尺度において「学習規律の 重視」と「楽しさの創出」,「公正な取り組み」が 最も強い相関関係を示したのは,「まもる」であ った.「まもる」が示すような社会的行動の中に は, 他者との関係を通した規律の遵守に関わる項 目が含まれており,これ自体は「学習規律の重視」 に関連すると考えられる，また，「まもる」には， 運動のルールやマナーの遵守に関する項目も含ま れており，それは「公正な取り組み」そのものを 示している.したがって, これらについて,「ま もる」と弱いないし中程度の有意な正の相関関係 が示されたことは概ね妥当な結果であると考えら れる.一方で,「楽しさの創出」が,「たのしむ」
よりも「まもる」と強い正の相関関係を示した点 は興味深い。これは「楽しさの創出」が, 実際に は「楽しさ」という情意面を示しているわけでは なく, 周囲との調和を意図するような学習方略を 示していることに起因すると推察される.このこ とから,「楽しさの創出」が, 社会的行動である「ま もる」と最も強い相関関係を示したこともまた, 妥当な結果であると考えられる.

「仲間との協力的な取り組み」と「挑戦的な取 り組み」「思考・判断」が最も強い相関関係を示 したのは,「できる」であった. 本研究において, 学習者は運動技術の習得にあたって, 仲間同士で の協力的な取り組みを重視することが明らかにな っており，ここでの「仲間との協力的な取り組 み」と「できる」の中程度の有意な正の相関関係 も, 本研究が示した知見と近似した結果を示した と考えられる，また，「できる」は，技術習得に 伴う学習者の運動への高い意欲が含まれることか ら,「挑戦的な取り組み」と中程度の有意な正の 相関関係を示したことは妥当な結果であると考え られる.さらに，自身のパフォーマンスへの理解 を深めながら取り組む「思考・判断」は,「できる」 に含まれるような自己の運動のできばえに対する 認知という点において関連があると推察されるこ とから, 弱いながらも有意な正の相関関係が示さ れたことは, 概ね妥当な結果であると考えられる。

最後に,「教師への関わり」は,「まなぶ」と弱 い有意な正の相関関係を示した.「教師への関わ り」は，学習者が知識を修得するにあたってまず 重視する方略であると推察されることから，概ね 妥当な結果であると考えられる.

以上, 体育学習観尺度・体育学習方略尺度と授 業評価尺度の関連は, 理論的にみても妥当なもの であったと考えられる.このことから, 本研究で

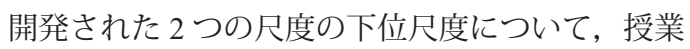
評価尺度の下位尺度との間に一定程度の基準関連 妥当性が確認されたといえよう。

したがって, 本調査での結果とも合わせ, 体育 学習観尺度と体育学習方略尺度の各下位尺度に は, 概ね満足できる信頼性と妥当性が確保されて いることが確認された。 


\section{VIまとめと今後の課題}

本研究の目的は,「中学生用体育学習観尺度」 および「中学生用体育学習方略尺度」を開発し, 体育授業における中学生の学習観と学習方略の関 連を明らかにすることであった。そのために，本 研究では，予備調査を実施した後，全国の公立お よび私立の中学生 2,498 名を対象として, 質問紙 調査法を用いた本調査を実施した。

まず，探索的因子分析を行った結果，体育学習 観尺度からは，「運動技術の習得」「「コミュニケ ーション能力の涵養」,「身体と運動に関する知識 の修得」「「運動の魅力の感受」,「身体能力の向上」 の 5 因子が抽出された。一方で，体育学習方略尺 度からは，「学習規律の重視」,「仲間との協力的 な取り組み」,「楽しさの創出」,「挑戦的な取り組 み」,「公正な取り組み」,「教師への関わり」,「思考・ 判断」の 7 因子が抽出された。両尺度には, 内的 一貫性と時間的安定性も確認することができたこ とから，十分な信頼性が確保されているといえよ う。さらには，一定程度の妥当性と因子不変性に ついても確認された。

次に, 開発した 2 つの尺度を用いて, 学年・性 別による違いを検討した結果，全ての因子におい て, 1 年生より $2 \cdot 3$ 年生の方が有意に高い傾向 にあること, 男子は仲間との協力, 女子は教師と の関わりを重視しながら取り組んでいることが明 らかになった。

そして，相関分析を用いて分析した結果，体育 学習観と体育学習方略の関連が明らかになった。

これにより，学習者が習得した知識や技術を活用 しながら, 学習課題の解決に取り組む姿が示され た。このことからも, 学習者は体育の学習内容を 理解しながら, その中に多様な学習観を見出すこ とによって，体育に関する知識の深化や技術を習 得するための多様な学習方略を用いているといえ よう.

以上, 本研究の検討により, 中学生の体育学習 観と体育学習方略のそれぞれの実態, そして, 体 育学習観と体育学習方略の関連を明らかにするこ
とができた，最後に，本研究で得られた知見を踏 まえて，教育実践への示唆を述べておきたい.

本調査の際に「これまで，『体育の授業で学ぶ 内容』や『体育の授業に対する自分の取り組みか た』について考えたことがあるか」と質問したと ころ， $71 \%$ （1,724人）の調査対象者が「考えた ことがない」と回答した．このことからも，自身 の学習観や学習方略というものは, 改めて他者か ら問われることがなければ，それに自覚的になる ことは容易でないといえる．自身の学習に対する 認知状態を把握することは，自身の学習行動を効 果的に調整するために不可欠な行動であると考え られるが（植阪，2010），学習者にとってみれば 容易く成し得るものではないだろう。

しかし，本研究で開発した尺度を用いれば，学 習者自身の体育に対する考え方ないし学習行動が 可視化され，自身の思考や行動に自覚的になるこ とができる，そのためには，今後，尺度の簡易化 も必要な作業となるが，こうした試みは，自らの 学習特性を自覚しようとするメ夕認知的な学習行 動の支援や，延いては，自律的な学習行動の促進 へとつながっていくと考えられる.

他方で, 教師にとってもまた, 単元前の「実態 調査」などで用いることで，授業実践の質の向上 が期待できる，これにより，教師は，対象とする クラスの学習者がこれまでどのような体育授業に 取り組んできたのか，また，どのような学習方法 を用いるのか，その特徴や傾向など，細やかな実 態把握が可能となるだろう。

新指導要領では, 学習者自らが学習課題の解決 に粘り強く取り組み, 学習の振り返りを通して 課題を修正したり，新たな課題を設定したりす るなどの学びの過程が重視される（文部科学省, 2017b)。こうした今後の教育要求に鑑みても，本 研究の試みは，体育の教育実践に資する意味で十 分な意義が認められると考える，今後は，以下の 課題を検討していくことで, さらなる研究の発展 と蓄積に努めたい.

1つ目に, 本研究では中学生に焦点を当てて検 討したが，今後は，小学生や高校生に対しても同 様に検討を行い, その上で, 小学校・中学校・高 
校といった各学校段階における体育学習観および 体育学習方略を横断的に分析していくことが必要 である.これによって, 各学校段階における体育 学習観および体育学習方略の特徵や, 学校移行時 における変化など，さらに幅広い知見を得ること ができると考える.

2つ目は，他の交絡因子との関連の検討であ る. 先行研究の蓄積の浅さから, 本研究はまず体 育学習観と体育学習方略に焦点を当てて検討した が, 今後は, 例えば, 実際の学習成果との関連, また学習動機といった要因を組み合わせて検討す ることにより, 体育の学習因果モデルを提示する ことができると考える.

そして，3つ目は，研究の目的でも述べたよう に，体育授業で用いるための簡易化した尺度の開 発である. 体育授業でも実施可能な項目数ないし 信頼性・妥当性を有した尺度を開発することによ り，教育実践の向上に寄与していくことができる と考える.

\section{謝辞}

調査にご協力いただきました中学校の先生方な らびに生徒の皆さまに, 心より感謝申し上げます。

\section{注}

注 1）伊藤（2001）は, 開発した尺度に命名をしていな いため, 本研究では「体育授業における学習方略を 測定する尺度」と表記した.

注 2）友添（2010）によれば, 体育の教科内容領域には, 「技術学習」,「認識学習」,「社会学習」,「情意学習」 の 4 つが挙げられる.

注 3）「教えあい」とは, 「学習者が互いに助けあい, 教えることで学ぶ一連の相互作用」(Goodlad and Hirst，1990，p.1）と定義される.

\section{文 献}

赤松大輔・藤岡秀樹（2015）英語科に関する学習観と英 単語学習方略との関連. 教育実践研究紀要, $15 ： 153$ 162.

中央教育審議会（2014）初等中等教育に扔ける教育課程 の基準等の在り方について (諮問). http://www.mext. go.jp/b_menu/shingi/chukyo/chukyo0/toushin/1353440. $\mathrm{htm}, \quad$ 参照日 2017 年 7 月 6 日).
Cohen, P. A., Kulik, J. A., and Kulik, C. C. (1982) Educational outcomes of tutoring : A meta-analysis of findings. American Educational Research Journal, 19 : 237-248.

藤村宣之 (2008) 知識の獲得・利用とメタ認知. 三宮真 知子編, メ夕認知: 学習力を支える高次認知機能. 北 大路書房, pp.39-54.

藤田勉（2012）中学生の体育授業における学業的援助要 請の学年差と性差の検討. 鹿児島大学教育学部教育実 践研究紀要, $22: 29-35$.

Goodlad, S. and Hirst, B. (1990) Explorations in peer tutoring. Nelson Thornes Ltd.

南風原朝和（2009）量的調查：尺度の作成と相関分析. 南風原朝和・市川伸一一下山晴彦編, 心理学研究法入門: 調査・実験から実践まで. 東京大学出版会, pp.6391.

長谷川悦示・高橋健夫・浦井孝夫・松本富子（1995）小 学校体育授業の形成的評価法及び診断基準作成の試 み. スポーツ教育学研究, $14: 91-101$.

速水敏彦 (1993) 外発的動機づけと内発的動機づけの間: リンク信条の検討. 名古屋大学教育学部紀要教育心理 学科, $40: 77-88$.

廣瀬友介・中本敬子・蛭田政弘 (2013) 数学学習におけ る学習観と学習方略の関係: 大学生を対象として分析. 文教大学教育学部紀要, $46: 45-56$.

堀野緑・市川伸一一奈須正裕（1990）基本的学習観の測 定の試み: 失敗に対する柔軟的態度と思考過程の重視. 教育情報研究, 6(2) : 3-7.

市原学・新井邦二郎（2005）中学生用数学・国語の学習 方略尺度の作成. 筑波大学心理学研究, 29:99-107.

市原学・新井邦二郎 (2006) 数学学習場面における動機 づけモデルの検討. 教育心理学研究, 54(2)：199-210. 市川伸一（2000）概念, 図式, 手続きの言語的記述を促 す学習指導 : 認知カウンセリングの事例を通しての提 案と考察. 教育心理学研究, 48(3) : 361-371.

市川伸一・南風原朝和・杉澤武俊・瀬尾美紀子・清河幸子・ 犬塚美輪・村山航・植阪友理 - 小林寛子・篠ヶ谷圭太 (2009) 数学の学力 ・学習力診断テスト COMPASS の 開発. 認知科学, $16: 333-347$.

市川伸一・堀野緑・久保信子（1998）学習方法を支える 学習観と学習動機. 市川伸一編, 認知カウンセリング から見た学習の相談と指導. ブレーン出版, pp.186202.

伊藤豊彦（2001）小学生における体育の学習動機に関す る研究 : 学習方略との関連および類型化の試み. 体育 学研究, $46: 365-379$.

鐘ヶ江淳一・江原武一・高橋健夫（1985a）生徒による 授業評価の検討 (1). 体育科教育, 33(5)：52-56.

鐘ヶ江淳一・江原武一・高橋健夫（1985b）生徒による 授業評価の検討 (2). 体育科教育, 33(6) : 52-56. 
北村剛志・森田愛子・松田文子（2003）児童の算数学習 への意欲と関連要因. 広島大学心理学研究, 2:109117.

Marton, F., Dall' Alba, G., and Beaty, E. (1993) Conceptions of leaning. International Journal of Educational Research, $19: 277-300$.

文部科学省（2008）中学校学習指導要領解説 保健体育 科編. 東山書房。

文部科学省 (2017a) 中学校学習指導要領. http://www. mext.go.jp/component/a_menu/education/micro detail/ icsFiles/afieldfile/2017/05/12/ 1384661_5_2.pdf，（参照日 2017 年 7 月 6 日).

文部科学省(2017b) 中学校学習指導要領解説 保健体育編. http://www.mext.go.jp/component/a_menu/education/micro_ detail/_icsFiles/afieldfile/2017/07/04/1387018_8_2.pdf, (参 照日 2017 年 7 月 6 日).

村山航（2003）学習方略の使用と短期的・長期的な有効 性の認知との関係. 教育心理学研究, 51(2) : 130-140. 成家篤史 (2012) 体育の学習観を問い直す。体育科教育, 60(10) : 36-39.

Nelson Le Gall, S., Gumerman, R. A., and Scott Jones, D. (1983) Instrumental help seeking and everyday problem solving : A developmental perspective. In: Depaulo, B., Nadler, A., and Fisher, J.(eds.) New directions in helping : Vol.2. Help seeking. Academic Press, pp.265-283.

岡田涼（2008）友人との学習活動における自律的な動 機づけの役割に関する研究. 教育心理学研究, 56(1)： 14-22.

押尾恵吾 (2017) 高等学校の教科における学習方略の横 断的検討：方略使用および有効性の認知に着目して。 教育心理学研究, 65(2) : 225-238.

Pintrich, P. R. and Zusho, A. (2002) The development of academic self-regulation: The role of cognitive and motivational factors. In: Wigfield, A. and Eccles, J. S.(eds.) Development of achievement motivation. Academic Press, pp. 249-284.

Purdie, N., Hattie, J., and Douglas, G. (1996) Student conceptions of learning and their use of self-regulated learning strategies : A cross-cultural comparison. Journal of Educational Psychology, 88: 87-100.

佐々木万丈・須甲理生（2016）体育授業に対する劣等コ ンプレックスの因子的概念と児童生徒の主体的要因と の関連. 体育学研究, $61: 663-680$.

瀬尾美紀子（2008）学習上の援助要請における教師の役 割：指導スタイルとサポート的態度に着目した検討. 教育心理学研究, 56(2)：243-255.
瀬尾美紀子・植阪友理・市川伸一（2008）学習方略とメ 夕認知. 三宮真智子編, メ夕認知：学習力を支える高 次認知機能. 北大路書房, pp.55-73.

篠ヶ谷圭太（2008）予習が授業理解に与える影響とその プロセスの検討：学習観の個人差に注目して．教育心 理学研究, 56(2) : 256-267.

篠ヶ谷圭太（2014）高校英語における予習および授業中 の方略使用とその関連：教師の授業方略による直接 効果と調整効果に着目して. 教育心理学研究, 62(3) : 197-208.

シーデントップ:高橋健夫訳（1981）楽しい体育の創造： プレイ教育としての体育. 大修館書店.

鈴木豪（2013）小・中学生の学習観とその学年間の差異. 教育心理学研究, 61(1)：17-31.

鈴木直樹（2014）構成主義的アプローチでよみがえる体 育授業. 体育科教育, 62(1)：24-27.

高田俊也・岡沢祥訓・高橋健夫（2000）態度測定によ る体育授業評価法の作成. スポーツ教育学研究，20 : 31-40.

高橋健夫（1989）新しい体育の授業研究. 大修館書店. 高橋健夫・長谷川悦示・刈谷三郎（1994）体育授業の「形 成的評価法」作成の試み：子どもの授業評価の構造に 着目して. 体育学研究, 39：29-37.

高橋健夫・岡澤祥訓（1994）よい体育授業の構造. 高橋 健夫編，体育の授業を創る. 大修館書店, pp.10-24.

辰野千壽（1997）学習方略の心理学：賢い学習者の育て 方. 図書文化社.

寺西友理（2008）高校生は数学の学習において公式・定 理をどのように捉えているか：学習観・学習方略・成 績との関連. 早稲田大学大学院教育学研究科紀要別冊, $16: 1-13$.

友添秀則 (2010) 体育の目標と内容. 高橋健夫ほか編著, 新版体育科教育学入門. 大修館書店, pp.30-38.

友添秀則（2017）学習指導要領の改訂とこれからの保健 体育. 中学保健体育科ニュース, $24: 2-5$.

植木理恵 (2002) 高校生の学習観の構造. 教育心理学研 究, 50(3) : 301-310.

植阪友理（2010） メ夕認知・学習観・学習方略. 市川伸 一編, 現代の認知心理学 5 発達と学習. 北大路書房, pp.172-200.

$\left(\begin{array}{l}2017 \text { 年 } 7 \text { 月 } 21 \text { 日受付 } \\ 2017 \text { 年 } 12 \text { 月 } 20 \text { 日受理 }\end{array}\right)$

Advance Publication by J-STAGE Published online 2018/2/15 